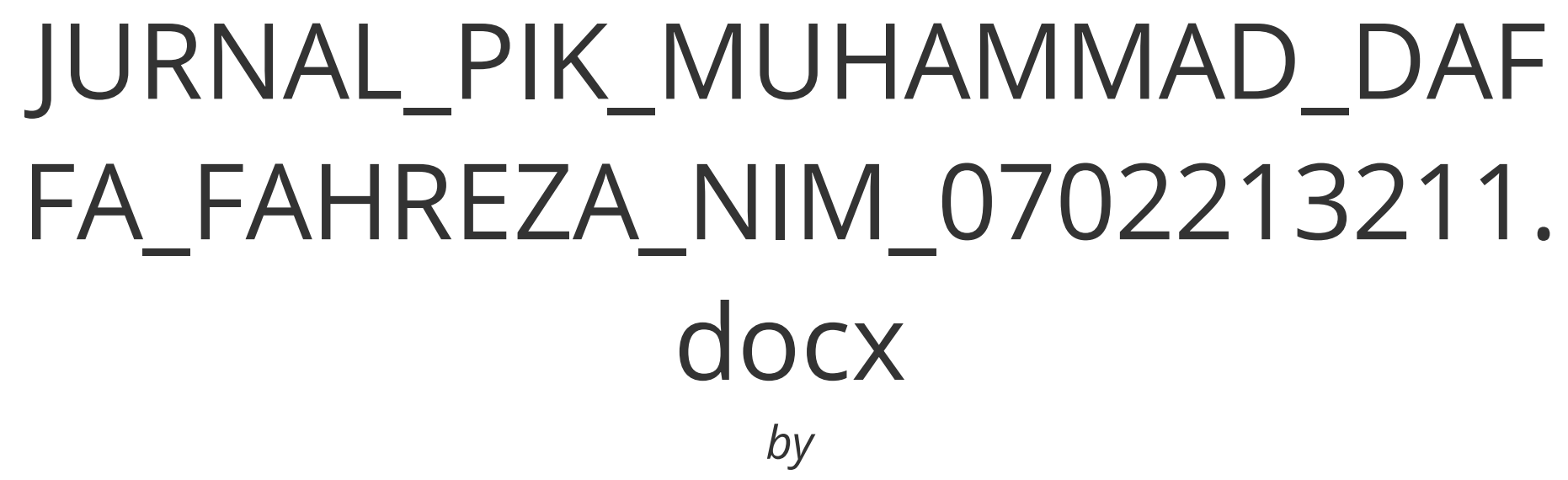

Submission date: 02-Jan-2022 03:40PM (UTC+0700)

Submission ID: 1736838927

File name: JURNAL_PIK_MUHAMMAD_DAFFA_FAHREZA_NIM_0702213211.docx (786.27K)

Word count: 3646

Character count: 23493 


\title{
PERBANDINGAN PENGGUNAAN SISTEM OPERASI WINDOWS DAN LINUX PADA KOMPUTER
}

\author{
COMPARISON OF USING WINDOWS AND LINUX OPERATING \\ SYSTEMS ON COMPUTERS \\ Muhammad Daffa Fahreza (0702213211) \\ 50 \\ Prodi Sistem Informasi, Fakultas Sains dan Teknologi , UIN SU
}

Daffafahreza107@gmail.com

\begin{abstract}
ABSTRAK
Saat ini era globalisasi semakin berkembang, hampir semua proses melibatkan teknologi. Oleh karena itu, meningkatkan penggunaan teknologi sangat berpengaruh besar terhadap perubahan dunia. Terlebih, banyak pekerjaan yang erat hubungannya dengan komputer.

29

Salah satu komponen yang vital adalah perangkat lunak atau software. Software adalah sebuah salah satu komponen pendukung dalam komputer berupa perangkat yang digunakan secara langsung oleh pengguna namun tidak dapat terlihat dan disentu ${ }_{43}$ pleh pengguna. Salah satu perangkat lunak yang sangat penting adalah system operasi.

Sistem operasi merupakan perangkat luna system yang berfungsi untuk menjalankan proses-proses yang ada dalam sebuah komputer. Beberapa contoh system operasi yang banyak digunakan oleh masyarakat adalah windows, linux, dan macOS. Namun, masih banyak juga pengguna yang masih bimbang dalam menentukan system operasi mana yang cocok dalam penggunaannya. Penelitian ini dilakukan dengan studi literatur. Hasil dari perbandingan adalah penggunaan system operasi tergantung pada kebutuhan setiap pengguna.
\end{abstract}

Kata Kunci - Komputer, Sistem Operasi, Perangkat Lunak, Windows, Linux

\author{
ABSTRACT \\ Currently the era of globalization is growing, almost all processes involve \\ technology. Therefore, increasing the use of technology is very influential in \\ changing the world. Moreover, many jobs are closely related to computers.
}


One of the vital components is software or software. Software is one of the supporting components in a computer in the form of a device that is used directly by the user but cannot be seen and touched by the user. One of the most important software is the operating system.

The operating system is system software that functions to run processes that exist on a computer. Some examples of operating systems that are widely used by the public are Windows, Linux, and macOS. However, there are still many users who are still undecided in determining which operating system is suitable for use. This research 45

was conducted by means of a literature study. The result of the comparison is that the use of the operating system depends on the needs of each user.

Keywords - Computer, Operating System, Software, Windows, Linux

\section{PENDAhuluan}

Pada era globalisasi yang semakin berkembang saat ini , hampir semua proses melibatkan teknologi. Dikarenakan hampir semua proses melibatkan teknologi dan dengan dilakukannya peningkatkan penggunaan teknologi akan sangat berpengaruh besar terhadap perubahan dunia. Terlebih, banyak pekerjaan yang berhubungan dengan komputer. Beberapa komponen yang mendukung sebuah komputer 51 ar dapat beroperasi adalah hardware, software, dan brainware. Ketiga komponen ini saling bekerjasama agar sebuah komputer dapat beroperasi atau berjalan.
Salah satu komponen yang mendasar adalah perangkat lunak atau software. Software adalah komponen pendukung dalam komputer yang berupa perangkat yang digunakan secara langsung oleh pengguna namun tidak dapat terlihat dan disentuh oleh pengguna. Software merupakan sumber atau otak dari sebuah komputer. Tanpa software, komputer tidak dapat beroperasi sebagai mana mestinya.

Perangkat lunak dapat digunakan untuk melakukan banyak kegiatan yang berkaitan dalam komputer. Contoh penggunaan software yaitu dalan editing video, membuat desain, bermain game, membu仿 sebuah program, dan lain lain. Salah satu 
perangkat lunak yang sangat penting adalah sistem operasi.

Sistem operasi merupakan software atau peragkat lunak sebuah sistem yang befungsi menjalankan prosesproses yang ada dalam sebuah komputer. Sistem operasi juga 40.fungsi mengatur hardware atau perangkat keras serta operasi dasar sistem yang $\operatorname{ad}_{55}$ pada komputer. Beberapa contoh sistem operasi yang digunakan oleh masyarakat adalah windows, linux, dan macOS. Namun , ada beberapa juga pengguna yang masih bingung dalam menentukan sistem operasi mana yang lebih efisien untuk digunakan.

Software merupakan data yang disimp an, diformat, dan diprogramkan secara digital dengan fungsi tertentu. Software juga tidak memiliki bentuk fi sik dan untuk mengoperasikannya bisa lewat perangkat komputer Pembuata $\mathrm{n}$ software memerlukan programming language yang ditulis oleh pemrogram yang kompeten dalam bidang tersebut , lalu perangkat tersebut dikompilasikan me makai aplikasi compiler.agar menjadi kode yang dapat dideteksi oleh mesin perangkat keras. Hardware yang dimaksud adalah Personal Computer atau komputer.

Perangkat lunak yang ada pada hardware tersebut merupakan nyawa dari komputer itu sendiri. Oleh karena itu , komputer tidak dapat dijalankan apabila tidak mengunduh sistem operasi pada komputer tersebut. Pasalnya , software tersebut berperan sebagai suatu perintah yang penting dalam program untuk menjalankan suatu kebutuhan pada sebuah komputer.

Dalam ilmu komputer, sebuah perangkat lunak adalah sistem operasi yang bertugas mengatur dan mengelola 58 perangkat keras, menjalankan aplikasi seperti program pengolah kata, operasi dasar sistem, desain animasi, database dan lain-lain.

Software juga dapat mengontrol operasi dari sistem komputer, dapat menyelesaikan masalah dalam sistem operasi, programming language, utility programme, dan application programme. Sistem operasi menyediakan suatu pustaka fungsi yang dapat menjadi solusi dalam permasalahan oleh aplikasi lain sehingga setiap pembuatan programme baru, fungsi-fungsi yang ada tidak perlu dibat dari awal.

\section{TINJAUAN PUSTAKA} Pengertian Perangkat Lunak Secara ilmiah, perangkat lunak adalah program dari data yang diprogram dan disimpan secara digitaI tidak dapat dilihat tetapi terkandung di komputer. Software berupa program dimana berfungsi menjalankan instruksi melalui perangkat lunak yang komputer dapat mengeksekusi atau mengeksekusi suatu instruksi. Perangkat lunak dapat juga dianggap sebagai driver dan pengontrol hardware. 
Singkatnya, software aplikasi adalah suatu sistem, program komputer yang berfungsi instalasi digital untuk membantu pengguna menyelesaikan tugas dan pekerjaan dalam bentuk pengolah kata, gambar, angka, dan suara. , dll. Selain itu, banyak fungsi lain yang terbagi ke beberapa kategori Selama masih menggunakan perangkat komputasi, maka tidak pernah lepas dari penggunaan software aplikasi dalam aktivitas pada hari-hari.

\section{7ngertian Komputer}

Alat yang digunakan untuk mengolah data sesuai dengan prosedur yang telah ditentukan disebut komputer. Awalnya, dalam komputer hampir semua proses informasi secara khusus menjelaskan tentang aritmatika , tetapi komputer pada era saat ini tidak hanya khusus tentang arimtatika, bisa juga untuk tugas yang tidak terkait dengan matematika.

\section{Pegertian Operasi}

Operasi mempunyai makna yaitu , pelaksanaan suatu kegiatan yang telah direncanakan sebelumnya

\section{2}

\section{Pengertian Sistem Operasi}

Sistem Operasi merupakan sebuah perangkat lunak yang menunjang operasi-operasi pada sistem aplikasi dan mengotrol semua perangkat tamnbahan pada computer supaya mampu bekerja sesuai dengan fungsinya. Selain itu, sistem gperasi juga dapat menjalankan sumber daya yang terdapat pada komputer serta menyediakan dasar agar application programme tersebut bisa dijalankan.

\section{Pengertian Sistem Operasi Komputer}

Sistem operasi yang terdapat pada computer atau dalam operating system (OS) merupakan sebuah perangkat lunak dengan fungsi untuk mengontrol dan meninjau perangkat keras serta operasi sistem dasar, contohnya dalam pelaksanaan aplikasi program pengolah data untuk memudahkan aktivitas manusia.

\section{METODE PENELITIAN}

Alur penelitian dilakukan dengan membaca st $46 \mathrm{i}$ literatur pada penelitian sebelumnya yang terkait dengan penelitian yang penulis lakukan. Pada tahap ini, penulis mengumpulkan materi yang berhubungan dengan penggunaan system operasi windows dan linux pada komputer serta kekurangan dan kelebihan yang terkandung di dalamnya. Analisis artikel dilakukan dengan menyaring jurnal dan buku yang berkaitan berdasarkan tahun terbit dan kata yang berkaitan yaitu windows dan linux.

\section{TINJAUAN PUSTAKA}

\section{Sejarah}


32

Perkembangan sistem operasi sangat

dipengaruhi oleh perkembangan

perangkat keras . Sistem operasi

diciotakan agar memudahkan dalam

penggunaan perangkat keras. Dengan

kata lain, seiring dengan

perkembangan dan kemajuan

perangkat keras, maka harus diikuti

dengan kemajuan dalam

perkembangan sistem operasi. Berikut merupakan perkembangan sistem operasi :

\section{A. Era pertama (1945 - 1955)}

Era pertama menandai dimulainya perkembangan sistem komputer elektronik untuk menggantikan sistem komputer mekanis. Hal ini disebabkan terbatasnya jumlah manusia yang rentan terhadap keq ${ }_{44}$ pbohan bahkan kesalahan. Karena tidak ada sistem operasi pada generasi ini, sistem komputer menerima instruksi yang harus segera dieksekusi. Pertama kali digital computer muncul pada awal tahun 1940-an, tetapi tidak memiliki sistem operasi. Program dimasukkan melalui kartu punch. Implementasi sistem operasi pertama kali dilakukan pada IBM 701 tahun 1950an oleh General Research Laboratories. Sistem operasi ini juga dikenal sebagai sistem pemrosesan batch aliran tunggal karena program dan data hanya dapat dikumpulkan secara individual dalam kelompok atau antrian (batch).

a. Era kedua (1955 - 1965)

Era kedua memperkenalkan sistem 30mrosesan batch dengan menjalankan beberapa tugas pada saat yang sama, tugas serial kemudian dieksekusi secara berurutan dan dapat berjalan dengan baik pada sumber daya komputasi. Berisi berbagai periferal, seperti pembaca kartu, kartu punch, printer, driver pita, dan drive. Di masa lalu, perancang OS sering terjebak dengan konsep bahwa jika satu tugas tertunda, perangkat $\mathrm{I} / \mathrm{O}$, dan prosesor menganggur, tugas lain menggunakan processor. Kemudian konsep tersebut dikembangkan menjadi multiprogramming, yaitu beberapa tugas ditempatkan di memori utama secara bersamaan dan processor 31pat memutarnya berdasarkan kebutuhan untuk menjaga efisiensi waktu.IBM meluncurkan sistem komputer berdasarkan sistem $/ 360$, dirancang untuk kompatibilitas yang lebih baik dengan dan perangkat keras pada tahun 19868. Sistem operasi ini kemudian dikembangkan untuk mendukung time sharing untuk melayani beberapa pengguna untuk berinteraksi di saat yang sama, yang menimbulkan kemungkinan bagi pengguna untuk berinteraksi melalui terminal dengan komputer Setiap developer kemudian mengembangkan teknologi time-sharing se 12 rti MIT, TSS, CTSS IBM. Di era ini, sistem komputer tidak dilengkapi dengan sistem operasi, tetapi memiliki beberapa fitur sistem operasi.

IBSYS dan FMS adalah contoh fungsi sistem operasi. 


\section{B. Era ketiga (1965 - 1980)}

Evoliusi pada sistem operasi dirancang untuk menanggapi pengguna yang banyak secara bersamaan. Pengguna berkomunikasi secara interaktif dengan komputer melalui terminal secara online sehingga sistem operasi menjadibanyak pengguna dan multiprogrammable(pengoperasia $\mathrm{n}$ banyak program). Sebagian besar, sistem tahun 1970-an ini menggunakan komputer mini dengan sistem pembagian waktu multimode yang mendukung pemrosesan batch, pembagian waktu, dan aplikasi waktu nyata. Komunikasi dalam LAN (Local Area Network). Pengkodean dan deskripsi mulai mendapat perhatian. Komponen utamanya adalah IC (integrated circuit). Selama

waktu ini beberapa konsep dikembangkan,seperti:

- Multiprogramming, satu prosesor mengeksekusi beberapa program pada memorti yang utama

- Multiprocessing, pekerjaan yang dilakukan beberapa processor untuk meningkatkan utilitas.

- Spooling (operasi periferal online simultan) hanya bertindak sebagai buffer dan dapat menerima instruksi bahkan jika instruksi tersebut belum dieksekusi.

- Device Independence, setiap komponen memiliki properti yang berbeda

- Time sharing

- Real time system

\section{Era keempat (Pasca 1980-an)}

Saat ini sistem operasi digunakan untuk jaringan komputer dimana pengguna menyadari adanya komputer ang saling terhubung. Dengan adanya Graphical User Interface (GUI) sebagai desain antarmuka computer menggunakan grafis yang nyaman.

2imulai saat ini dimana komputasi tidak lagi berpusat pada suatu titik, tetapi dipecah oleh banyak komputer, sehingga kinerja lebih baik. diperoleh. Dengan pengembangan sirkuit LSI (Large Scale Integration), ribuan transistor per chip telah diintegrasikan ke dalam komputer pribadi. Dari segi arsitektur, komputer pribadi (awalnya disebut mikrokomputer) tidak jauh berbeda dengan komputer mini kelas PDP11. Chip mikroprosesor memungkinkan seseorang untuk memiliki komputer sendiri.

D. Era Kelima (Pasca 1990-an)

Sering disebut sebagai ponsel yang bisa dibawa kemana saja dan menjalankan berbagai sistem operasi seperti Android, Symbian dan iOS dari Apple. 


\section{Fungsi Dasar pada Sistem Operasi}

Sistem Operasi memiliki beberapa fungsi yaitu ${ }_{53}$ memliki fungsi untuk mengelola perangkat lunak dan perangkat keras maksudnya adalah sistem operasi dapat mengsinkronisasi komputer untuk menjalankan program atau aplikasi sesuai dengan keinginan pengguna komputer tersebut. Selain itu , sistem operasi juga berfungsi untuk mengatur permasalahan yang terjadi $\operatorname{pad}_{20}$ pengguna, dengan cara ketika pengguna menggunakan sumber daya yang sama, sistem operasi akan memilih pengguna mana yang dapat mengakses sumber daya tersebut dan fungsi yang sangat penting dari sistem operasi adalah program operasi dapat mencegah dan mengatasi kesalahan dan penggunaan komputer yang tidak harus digunakan

Adapun dibawah ini merupakan fungsi sistem operasi secara umum yaitu sebagai berikut :

- Resource manager adalah pengelolaan sumber daya dan mengalokasikannya. Misalnya memori, cpu, disk drive dan perangkat lainnya.

- Interface atau tatap muka, yaitu mediasi antara pengguna dan perangkat dengan menyediakan antarmuka pengguna yang lebih ramah pengguna dan mudah dipahami.

- Graphical user interface (GUI), yang menyediakan informasi tentang perangkat keras, baik aktif maupun pasif, dan mengontrol perangkat $\mathrm{I} / \mathrm{O}$ (perangkat input/output)

- Coordinator, mengkoordinasikan, dan menyediakan sarana yang 8engannya kegiatan-kegiatan kompleks dapat diatur dan ditangani secara berurutan.

- Guardian, memberikan kontrol akses dengan tugas melindungi file dan memantau data dan program Penjaga Gerbang, yang mengontre 25 akses pengguna dengan mengontrol siapa yang memiliki akses ke sistem dan memantau apa yang mereka lakukan.

- Gate Keeper adalah penjadwal input pengguna (input), akses database, proses TI, dan penggunaan.

- Accountant mengelola waktu CPU, penggunaan memori, panggilan I/O, drive penyimpanan, dan waktu koneksi terminal.

\section{Sasaran Sistem Operasi}

Selain melakukan pelayanan terhadap pengguna atau user sistem operasi juga setidaknya mempunyai tiga sasaran utama yaitu

a. kenyamanan pengguna, dari segi kenyamanan sistem operasi harus membuat pengguna nyaman dengan komputer atau sistem operasi harus dapat melakukan tugasnya 
tanpa diganggu oleh hal lain.

b. Agar dapat digunakan secara efektif, sistem operasi harus dapat memanfaatkan

kemampuan hardware dan software pada komputer dengan sebaikbaiknya. Dibandingkan dengan Scalable, sistem operasi harus dapat berkembang dan dapat menambahkan

fungsionalitas baru ke sistem operasi, atau ke perangkat lunak atau perangkat keras komputer.

\section{Tujuan Sistem Operasi}

Sistem operasi dapat mengatur kinerja program pada aplikasi, dengan demikian sistem operasi memiliki tujuan :

a. Sistem operasi memudahkan komputer dalam menjalakan 59pgram aplikasi.

b. Sumber daya sistem komputer memiliki cara yang lebih efisien dengan adanya sistem operasi.

Sistem operasi harus sesuai 5engan susuanannya , sehingga memungkinkan pengembangan yang lebih efektif agar pengujian dan penerapan fungsi-fungsi sistem baru tidak mengganggu layanan yang

telas ada.

\section{Jenis-Jenis Sistem Operasi}

\section{A.Sistem Operasi Windows}

Windows adalah sistem operasi yang dikembangkan oleh Microsoft Corporation yang menggunakan GUI (Graphical User Interface) atau antarmuka berbasis antarmuka pengguna grafis.

\section{B.Sistem Operasi Linux}

Linux adalah artifisial dari MINIX (varian dari UNIX). Sistem operasi ini juga sudah dikenal dan digunakan oleh banyak orang. Linux didasarkan pada sistem operasi POSIX standar yang diturunkan dari UNIX itu sendiri.

\section{C.Sistem Operasi MACINTOSH}

$$
13
$$

MACINTOSH adalah sistem operasi pertama yang menggunakan antarmuka pengguna grafis (GUI) dan dirancang secara khusus oleh Apple komputer upuk komputer Macintosh ,sehingga sistem operasi ini tidak kompatibel untuk digunakan oleh komputer IBM.

D.Sistem Operasi Symbian

Symbian merupakan sistem operasi yang dikembangkan oleh Symbian Ltd dan dirancang untuk digunakan pada perangkat seluler atau ponsel, tetapi tidak dapat digunakan secara bebas.

E. Sistem Operasi Android

Android adalah sistem operasi Linux yang dikembangkan dan dirancang untuk aplikasi portabel atau portabel. 


$$
\begin{aligned}
& \text { Android menyediakan platform } \\
& \text { terbuka bagi pengembang untuk } \\
& \text { membuat aplikasi mereka sendiri } \\
& \text { F. System operasi Palm }
\end{aligned}
$$

Palm adalah sistem operasi seluler yang dikembangkan oleh Palm, Inc. Contoh produk yang terintegrasi dengan sistem operasi Palm adalah Palm Treo 680

\section{G. System Windows Mobile}

Windows Mobile merupakan sistem operasi yang dibuat oleh Microsoft untuk perangkat seluler.

\section{H. .Sistem Operasi BlackBerry}

BlackBerry dikembangkan oleh Research In Motion dan merupakan sistem operasi seluler yang menyediakan multitasking dan mendukung perangkat input khusus yang telah diadopsi RIM untuk digunakan pada perangkat genggam, yaitu roda, trackball, dan yang terbaru trackpad, mouse, dan layar sentuh.

4. Sistem operasi sebagai pengelola sumber daya komputer

Sebagaimana adanya, fungsi sistem operasi adalah untuk mengatur dan mengendalisan sumber daya yang ada,pada sistem komputer tersebut dan semua komponen yang memberikan fungsi (manfaat) pada sistem komputer tersebut Sumber daya komputer dibagi menjadi dua, 3aitu:

1. Sumber daya Fisik
Sumber daya fisik merupakan semua komponen yang ada dalam sistem komputer yang ${ }_{56}$ angat berguna bagi komputer dan dapat kita lihat secara fisik, misalnya:

Terdiri 3 lari beberapa komponen seperti CPU, motherboard, bios / cmos, power supply.

Keyboard, mouse, joystick, dan trackball

3

2. Sumber daya abstrak Sumber daya abstrak terbagi me 22 adi 2 yaitu :

a. Data

Data adalah sesuatu yang tidak memiliki arti bagi penerimanya dan masih memerlukan pengolahan dan dapat berupa situasi , huruf, angka , gambar , dan lain-lain. Data juga dapat kita gunakan untuk melihat objek, atau konsep

. Contoh :

- PCB (program control block ) untuk perekaman dan kontrol proses

3 FiIe sebagai penyimpanan data atau program

- Semaphore untuk mengontrol sinkronisasi proses

\section{Program}

Program merupakan sekumpulan instruksi yang dapat dijalankan oleh sistem komputer. Contoh jenis program bisa seperti utilitas atau aplikasi untuk mencapai tujuan 
komputasi (pemrosesan) tertentu. Pengguna dapat melihat 35 istem komputer sebagai satu paket layanan yang disediakan oleh sistem operasi.

Sistem operasi harus membuat penggunaan komputer lebih mudah digunakan dan lebih efisien yang 34 akukan dengan cara memfasilitasi pengembangan, pengujian, dan penyerahan fungsi baru tanpa menganggu layanan yang disediakan sebelumnya. Sistem operasi komputer memiliki beberapa tugas untuk menangani dan mengontrol sumber daya, seperti multitasking , multiprocessing , timesharing , multithreading, dan scability and network.

Jika tidak adanya sistem operasi, pengguna tidak dapat menggunakan program aplikasi di komputer mereka, kecuali program aplikasi startup (Booting). Begitu juga dengan kemampuan komputer yang dapat dihubungkan dengan terminal, printer atau peralatan tambahan lainnya. Oleh karena itu, dengan sistem operasi ini, pengguna harus dapat memanfaatkan komputer secara maksimal.

\section{HASIL DAN PEMBAHASAN}

Berdasarkan jurnal dan Buku referensi yang diambil berikut kelebihan dan kekurangan serta pengertian dari windows dan linux :

\section{WINDOWS}

Windows adalah sistem operasi yang dikembangkan oleh Microsoft
Corporation yang menggunakan GUI (Graphical User Interface) berbasis antarmuka pengguna grafis. Sejak dahulu, sudah banyak pengguna yang menggunakan sistem operasi ini. Awalnya Windows tetap $\mathrm{d}_{57} \mathrm{~m}$ kategori MsDos (Microsoft Disk Operating System), yang nquupakan sistem operasi berbasis teks dan Command-Line interpreter. Dan Windows 1.0 berkembang ke versi terbaru sejauh ini, yaitu Windows 11 .

\section{LINUX}

Linux adalah sistem operasi open source yang didistribusikan secara bebas di bawah lisensi GNU. Linux adalah salah satu 49 dari contoh peningkatan pada perangkat lunak yang bisa lidapatkan secara gratis dan sebagai sumber terbuka utama Seperti perangkat lunak bebas dan sumber terbuka lainnya hingga pada umumnya, kode sumber Linux dapat dimodifikasi secara bebas, dan dapat digunakan atau didistribusikan kembali secara bebas oleh siapa saja.

Linux dip 8 kenalkan secara publik di Finlandia oleh Linus Torvalds pada tanggal 5 Oktober 1991, ketika ia masih menjadi mahasiswa ilmu 1 .6mputer di Universitas Helsinki. Lisensi Linux dipegang oleh Linus Torvalds sebagai penghormatan kepada kerja keras dalam pengembangan Linux. Linux memiliki distribusi, dimana berisi batch dari aplikasi, dimana digunakan secara khusus. Gunakan Linux dan dalam kombinasi dengan . Yang paling (16)um digunakan disebut distribusi Linux. Ada beberapa distro Linux 
yang telah mengembangkan . Yaitu, Suse, Debian,dan lain - lain .

Linux , berada di jaringan sistem.

1. KELEBIHAN

KEKURANGAN LINUX DAN WINDOWS

\section{A. KELEBIHAN LINUX}

- Sistem operasi pada Windows 14bih mudah digukanan atau user friendly dibandingkan dengan sistem operasi yang lain.

- Proses instalasi software lebih mudal $_{26}$ dilakukan dan tidak rumit dibandingkan

- dengan instalasi sistem operasi yang lain

- Ada banyak software yang berlandaskan atau berbasis Windows.

\section{B. KEKURANGAN LINUX}

- Pada dasarnya seluruh data disimpan pada hard drive meskipun terdapat syarat

- eksklusif pada mana data disimpan pada hard drive. Linux / UNIX menyediakan mekanisme spesifik buat mengakses terminal, printer, \& perangkat keras lainnya seolah-olah kita sedang mengakses arsip yg disimpan pada hard drive atau floppy disk.

- Linux merupakan acara asal terbuka \& gratis

KELEBIHAN DAN KEKURANGAN WINDOWS
A. KELEBIHAN WINDOWS

- Sistem operasi pada Windows lebih mudah atau lebih ramah pengguna dibandingkan sistem operasi lain.

- Proses instalasi perangkat lunak lebih sederhan 14 dan tidak rumit dari dengan instalasi sistem operasi yang lain.

- Software yang berlandaskan Windows terbilang cukup banyak.

\section{B.KEKURANGAN WINDOWS}

- Windows adalah sumber tertutup atau tidak terbuka untuk umum, yang mengurangi komunitas pengguna.

- Windows sangat rentan terhadap serangan dan sering terinfeksi virus.

- Keamanan pada sistem Windows masih kurang

\section{PERBEDAAN LINUX DAN WINDOWS}

Ada beberapa perbedaan antara LINUX dan Windows yaitu:

\section{Hardware Support}

Di Windows, jarang terdengar adanya masalah perangkat keras, dikarenakan hampir semua perangkat keras yang ada memeperturutkan driver. Tidak seperti Linux di mana sering terdengar bahwa perangkat keras tidak berfungsi di Linux, dikarenakan pabrikan perangkat keras tidak menyajikan driver versi Linux. Akan tetapi, banyak vendor baru-baru ini 
memberikan dukungan untuk driver Linux. Dan munculnya hardware di Linux semakin banyak, sehingga jarang sekali kita mendengar tentang masalah perangkat keras pada Linux.

\section{Menangani Crash}

Linux umumnya dianggap seperti hal nya sistem operasi yang teratur atau stabil. Peisandingan

antara Linux dengan Windows 95/98 /ME, Linux jauh lebih stabil. Dan, seperti Windows, suatu saat Linux akan bermasalah. Dalam kasus yang jarang terjadi, program mungkin 7 macet atau macet. 12 Unix dan Linux memiliki sifat yang multi-user, tetapi Linux menjalankan aplikasi secara berbeda dari Windows. Jika aplikasi terkunci, Anda cukup mematikannya. Cukup tekan pintasan keyboard Ctrl + Esc untuk mengakhiri proses yang menyinggung. Jika sistem grafis Linux Anda terkunci, Anda dapat menekan Ctrl + Alt + F1 \& \# 41; untuk membuka Command Prompt \& \#40;. Mengakhiri proses per angkat lunaksecara manual.Anda juga memiliki opsi untukme-

restartdesktop Anda dengan menekan Ctrl + Alt + Backspace. Jika terjadi kesalahan dengan sistem Linux tersebut , Anda tidak perlu melakukan boot ulang.

\section{Sistem File}

Contoh Sistem Fige yang terdapat di Windows yaitu FAT (dari DOS dan Windows 9x) dan NTFS (dari
Windows NT/2000/XP). Jika kita memiliki file dan ingin menyimpan sekaligus membaca fike tersebut dapat dengan menggunakan sistem FAT dan NTFS ${ }_{7}$ Windows. Windows belum dapat membaca atau menulis file di sistem Linux karena belum berlaku. Adapaun contoh jenis sistem file pada Linux, termasuk ReiserFS (rfs) atau Ext3. Dalam beberapa hal, sistem ini lebih unggul daripada Windows FAT atau NETS karena memanfaatkan teknik atau cara yang disebut logging. Sementara $\log$ ini menyimpan $\log$ sistem file. Ketika sistem Linux crash, logging akan selesai setelah menyalakan ulang dan semua file pada hard drive akan terus berjalan normal.

\section{KESIMPULAN}

\section{7}

Sistem operasi merupakan perangkat lunak yang mengontrol dan mendukung semua operasi komputasi, beberapa contohnya adalah mengendalikan perangkat komputasi agar dapat berfungsi dengan baik dan mendukung operasi pada sistem tersebut. Contoh sistem operasi ${ }_{4}$ r rbasis perangkat lunak adalah Windows dan LINUX. Perbedaan besar antara Windows dan LINUX adalah Linux merupakan sistem operasi bersifat terbuka yang didistribusikan secara bebas 23 bawah lisensi GNU, sedangkan Windows adalah sistem operasi yang dimajukan oleh Microsoft Corporation menggunakan antarmuka berbasis GUI dan sistem operasi ini juga tersedia dengan biaya. Selain itu 
LINUX memiliki kekurangan yaitu tampilannya masih belum user friendly, sedangkan layar Windows sudah user friendly.

Dari hasil analisis penulis dapat disimpulkan bahwa penggunaan sistem operasi yang tepat tergantung dari kebutuhan masing-masing pengguna yang akan menggunakan sistem operasi tersebut.

\section{Daftar Pustaka}

[1] M. F. M. I. SAMSUDIN, PENGENALAN KOMPUTER DAN TEKNOLOGI INFORMASI, MEDAN: PERDANA PUBLISHING, 2019.

[2] Yahfizham, Dasar- Dasar Komputer, Medan: Perdana Publishing, 2015.

[3] M. Ismail, "Cara Kerja Sistem Informasi," p. 12, 2015.

[4] H. Sugiarto, "Sistem Operasi Windows," Sistem Operasi WIndows, p. 11, 2015.

[5] A. HARDIENA, LINUX FUNDAMENTAL, BEKASI SELATAN: IGOS CENTER BEKASI, 2015.

[6] A. s. v. P. Abhilash, "International Journal of Engineering Research and
Applications," Comparison of Windows and Linux Operating Systems in Advanced Features, p. 3, 2015.

[7] Nelfira dan Diana Silvia. (tahun) Rancang Bangun Aplikasi Pembelajaran Sistem Operasi Windows Pada Matakuliah Sistim Operasi di STMIK Indonesia Padang Berbasis Multimedia Interaktif.", Jurnal Edik Informatika

[8] Irianto, Jelang Fajar. Perkembangan Sistem Operasi Windows, It Sharing for Indonesia Open Knowledge (ILMUTI).

[9] Anthu Priya Rani. P dan Rohini V. Performance Evaluation of Recent Windows Operating Systems, International Journal of Innovative Reasearch in Advaced Engineering (IJIRAE),

[10] Agustina, I., Sistem, J., \& Universitas, I. (2009). E-COMMERCE DENGAN MEMANFAATKAN SISTEM OPERASI LINUX. 2009(semnasIF) 
JURNAL_PIK_MUHAMMAD_DAFFA_FAHREZA_NIM_07022132...

ORIGINALITY REPORT

$26 \%$

SIMILARITY INDEX
$26 \%$

INTERNET SOURCES
$1 \%$

PUBLICATIONS
$8 \%$

STUDENT PAPERS

PRIMARY SOURCES

1 informaraka.blogspot.com

Internet Source

2 febryaniclara8.wordpress.com

Internet Source

3 uniquesciences.wordpress.com

Internet Source

4 www.sayanda.com

Internet Source

5 iwanjuniarto010.blogspot.com

Internet Source

6 ilmukomputer.org

Internet Source

7 radityacukwibowo.wordpress.com

Internet Source

8 WwW.slideshare.net

Internet Source 
10 iptektikom.blogspot.com

11 WWW.zona1000.com

12 muja2661.blogspot.com

13

es.scribd.com

Internet Source

14 sigitbuslovers.blogspot.com

15 idoc.pub

16 tokooscar.blogspot.com

17 ardilah12.blogspot.com

Internet Source

18 id.scribd.com

19 invictusneverdie.wordpress.com 
Student Paper

23 hapismarine.wordpress.com

24 widuri.raharja.info

25 4winmobile.com

26 afkey.blogspot.com

Internet Source

27 caramenuliscerpenpengalaman.wordpress.com

28 digilib.iain-palangkaraya.ac.id

29 rifqimulyawan.com

30 sarifahparifdah.blogspot.com

Internet Source

31 sisteminformasi2016site.wordpress.com 
34 imrownsetyawan.wordpress.com Internet Source

35 indonesia2013.blogspot.com

36 yudhos.wordpress.com

37 Submitted to Universitas Negeri Jakarta Student Paper

38 arifshofwan.blogspot.com Internet Source

39 docplayer.info Internet Source

40 firdaustkjsmkn2tembilahan.blogspot.com Internet Source

41 freeverizonringtonesftt.blogspot.com Internet Source

42 jurnalmahasiswa.unesa.ac.id Internet Source

kavinadinugraha.wordpress.com 
46 pt.scribd.com

49 gadisidhani.blogspot.com

48 tl301.ilearning.me

50 journal.uin-alauddin.ac.id

51 library.binus.ac.id 
57 khusnadi1996.blogspot.com

58 postmyentri.blogspot.com 